\title{
Gerando vida em contexto de morte: o exercício materno em situações de militância durante a Ditadura Militar no Brasil (1964-1985)
}

\author{
Creating life in the context of death: the maternal exercise in militancy situations during \\ the Military Dictatorship in Brazil (1964-1985)
}

\author{
Jaíza Pollyanna Dias da Cruz ${ }^{1}$ \\ Ingrid Faria Gianordoli-Nascimento ${ }^{2}$ \\ Flaviane da Costa Oliveira ${ }^{3}$ \\ Thayna Larissa Aguilar dos Santos 4 \\ Bárbara Gonçalves Mendes ${ }^{5}$ \\ Janaína Campos de Freitas ${ }^{6}$ \\ Débora Barbosa dos Reis ${ }^{7}$
}

\begin{abstract}
RESUMO: Este trabalho objetiva compreender a experiência de maternidade de mulheres que militaram durante o período da Ditadura Militar no Brasil (1964-1985). Foram realizadas quatro entrevistas com mulheres que estiveram grávidas e conceberam seus filhos no período de militância, durante a clandestinidade, prisão, exílio e pós-soltura. Para a organização e interpretação dos dados, realizamos análise de conteúdo temática. Os resultados e a discussão foram organizados em torno de duas grandes categorias: Maternidade e Militância: compreendendo as tensões entre o individual e o coletivo e Nascendo nos porões da ditadura: gerando vida em um contexto de morte. Apesar de vivenciarem um contexto no qual a morte era um risco proeminente, a maternidade contribuiu para a preservação de suas vidas, não impedindo, porém, que estas mulheres, mesmo grávidas, sofressem torturas físicas, sexuais e psicológicas, além de ameaças em relação à continuidade da gravidez e à permanência de seus filhos junto a si.
\end{abstract}

Palavras-chave: maternidade; gênero; identidade feminina; militância; ditadura militar no Brasil.

ABSTRACT: This work's aim is to comprehend the maternity experience of women who militated during the period of the military dictatorship in Brazil (1964-1985). Four interviews were carried out with women who were pregnant and gave birth to their children in the period of militancy, during clandestinely, prison, exile and amnesty. For the organization and interpretation of data, we accomplished thematic content analysis. The results and the discussion were organized around two

\footnotetext{
1 Mestre em Psicologia pelo Programa de Pós-Graduação em Psicologia da Universidade Federal de Minas Gerais -Belo Horizonte, Brasil. E-mail: jaizacruzz@gmail.com.

2 Doutora em Psicologia; Coordenadora do Programa de Pós-Graduação em Psicologia da Universidade Federal de Minas Gerais e docente do Departamento de Psicologia da Universidade Federal de Minas Gerais - Belo Horizonte, Brasil.

3 Mestre em Psicologia pelo Programa de Pós-Graduação em Psicologia da Universidade Federal de Minas Gerais - Belo Horizonte, Brasil.

${ }^{4}$ Graduanda do curso de Psicologia da Universidade Federal de Minas Gerais; Bolsista de iniciação científica da Fundação de Amparo à Pesquisa de Minas Gerais (FAPEMIG) - Belo Horizonte, Brasil.

${ }_{5}^{5}$ Mestranda em Psicologia pelo Programa de Pós-Graduação em Psicologia da Universidade Federal de Minas Gerais - Belo Horizonte, Brasil.

${ }^{6}$ Mestranda em Psicologia pelo Programa de Pós-Graduação em Psicologia da Universidade Federal de Minas Gerais - Belo Horizonte, Brasil.

${ }^{7}$ Graduanda do curso de Psicologia da Universidade Federal de Minas Gerais - Belo Horizonte, Brasil.
} 
broad categories: Maternity and militancy: understanding the tensions between the individual and the collective; and Being born in the dictatorship basements: creating life in the context of death. Though experiencing a context in which death was a prominent risk, maternity contributed to the preservation of their lives, however, it did not prevent these women, despite being pregnant, from suffering physical, sexual and psychological tortures as well as threats on the continuity of their pregnancy and on the permanence of their children with them.

Keywords: maternity; gender; female identity; militancy; military dictatorship in Brazil.

\section{Introdução}

O período da Ditadura Militar no Brasil ocorreu em meio a mudanças e transformações dos costumes, em que as fronteiras entre público e privado se modificavam, principalmente, em função do processo de modernização e industrialização do país (Matos, 1995; Biasoli-Alves, 2000). De acordo com Almeida e Weis (1997), o período de 1964 a 1985 foi caracterizado por um gradativo endurecimento do Regime, instituído por meio dos Atos Institucionais (Al) que marcam importantes divisões que caracterizam as mudanças político-sociais durante o período autoritário". Do "Al ao Al-5", o Brasil passou por ciclos de abertura e fechamento do espaço público, tanto em relação aos movimentos políticos, e das liberdades, quanto à vida individual e coletiva. Formaram-se e fortaleceram-se, neste período, partidos políticos de esquerda, o movimento estudantil, através da União Nacional dos Estudantes (UNE), além de outras associações que iam às ruas questionar a ordem estabelecida autoritariamente (Almeida \& Weis, 1997). Para estes autores, este foi um momento de ambiguidade das fronteiras entre proibido e o permitido e entre o espaço público e privado. Antes da promulgação do Ato Institucional de número 5 (Al-5) em 13 de dezembro de 1968, havia ainda um clima de esperança, muito fortalecido pelos ideais socialistas revolucionários, que envolvia parte dos manifestantes, nesta altura, considerados como comunistas e perturbadores da ordem pública.

Grande parte destas pessoas pertencia à classe média brasileira, formada por universitários, intelectuais e artistas, que se engajaram no movimento contra o Governo autoritário, principalmente com o endurecimento repressor que se deu após a instituição do Al5 - os chamados "Anos de Chumbo". Neste período, intensificou-se a censura e a restrição à liberdade de expressão político-social, institucionalizando as práticas de cassação, prisão e tortura contra aqueles considerados opositores ao regime, nomeados pelo Estado de "subversivos" e/ou "terroristas".

Dentro destes grupos de esquerda destaca-se a importância social da participação de mulheres na militância em oposição à Ditadura Militar. Segundo Ferreira (1996), esta participação configurava-se em uma contravenção em relação a dois pontos específicos: “... as militantes estavam desempenhando um papel duplamente transgressor: enquanto agentes políticos (insurgindo-se contra o Regime) e enquanto gênero (rompendo com o padrão vigente)" (p. 152). Por outro lado, a militância feminina foi também questionada e criticada inclusive por outras mulheres, que não aderiram a este tipo de luta e mantinham a tradição, reconhecendo o "seu" lugar de mãe, esposa e dona-de-casa, apoiando e legitimando o Regime

${ }^{8}$ Almeida e Weis (1997) propõem uma divisão didática para as mudanças que caracterizam o período ditatorial brasileiro: do Al ao Al-5 (1964-1968); do Al-5 ao início da abertura (1969-1974); à longa transição rumo ao governo civil (1975-1984). 
Militar, criando inclusive movimentos como as "Marchas da Família com Deus pela Liberdade" (Ridenti, 1990, p. 3).

Vários estudos enfatizam as importantes transformações que se deram em relação ao lugar social feminino e a inserção da mulher no contexto de militância político e social, durante e após a Ditadura Militar (Ridenti, 1990; Ferreira, 1996; Colling, 1997; Goldenberg, 1997; Sarti, 2004). Sistematizar e trazer à tona a história dessas mulheres nos permite compreender a construção da identidade feminina por meio das vivências, marcadas por mudanças e continuidades. No entanto, se mudanças podem ser vistas no cenário público/político em relação à ação feminina, no que tange aos aspectos referentes ao privado, pouco se tem investigado, e uma destas dimensões é o exercício da maternidade em meio à militância (Veloso, Gianordoli-Nascimento \& Ferreira, 2010; Gianordoli-Nascimento, Trindade \& Santos, 2012).

Conforme aponta o estudo realizado por Veloso et al. (2010) sobre a representação social da maternidade entre mulheres militantes, ser mãe e ser militante apresentava certa ambivalência, pois se contestavam de um lado, os padrões vigentes, e do outro, se repetia o que era tradicional, configurando-se como um conflito para as mulheres militantes, que tiveram que decidir entre o exercício pleno da maternidade ou pela continuidade da militância. De outra forma, a condição da maternidade “... também representou para essas mulheres a possibilidade de reconstrução de suas vidas, motivo pelo qual precisavam enfrentar a realidade após o aniquilamento sofrido na tortura..." (p. 7). A estas mulheres se colocava, contudo, a decisão entre uma condição ou outra, e o contrabalanço entre os projetos individuais e coletivos.

Remontar esse cenário político em que as mulheres se inseriram é de suma importância para o entendimento acerca desse contexto social, que modificou as relações de gênero e o lugar social da mulher. Sendo assim, a atuação destas mulheres favoreceu novos modelos e configurações sociais que contribuíram para a inserção da mulher em uma nova ordem social, diluindo as fronteiras entre a vida pública e privada, o que nos permite investigar as dinâmicas da maternidade nesse contexto, compreendendo que a maternidade se constitui como um dos pilares fundamentais da identidade feminina (Carson, 1995).

Sendo assim, o objetivo geral deste estudo é compreender a experiência da maternidade conjugada à militância política, enfatizando a compreensão do lugar social da mulher militante a partir das experiências, das lembranças e narrativas de suas vivências. Para tanto, esta investigação se embasa em produções científicas que se debrucem sobre as vicissitudes da vivência da maternidade em situações-limite, e em especial durante o período da ditadura militar, articulando analiticamente as dimensões do gênero e da militância.

Neste sentido, cabe enfatizar que há poucos trabalhos que exploram essas conexões, situação que reflete um quadro mais amplo da composição da memória social do período, que mesmo após quase trinta anos do final do regime ainda obscurece aspectos das vivências de vários segmentos sociais que atuaram direta ou indiretamente na cena político-social do Brasil. Assim, ao trabalharmos com os relatos orais das entrevistadas entramos em contato com vivencias que ilustram as transformações da identidade feminina, advindas do rompimento de padrões socialmente esperados em relação a atuação pública e a experiência privada de mulheres. 
Estas mulheres vivenciaram situações-limites após a entrada na militância, romperam com seus vínculos familiares e assumiram riscos sociais ao: engravidarem solteiras; serem presas grávidas; sofrerem abortos sob tortura; terem seus partos durante a prisão, clandestinidade e exílio, sem assistência médica pré e pós-parto; além de serem apartadas de seus bebês sem amamentá-los e sob ameaça de não mais tê-los nos braços.

Tais situações exigiram destas mulheres capacidades de resistência e superação frente ao adverso, principalmente no período pós-prisão, quando tiveram que reconstruir suas vidas e laços sociais, conjugando maternidade, carreira e sobrevivência em um amálgama pouco experienciado pelas mulheres de classe média daquele período histórico. Investigar a participação da mulher dentro desta conjuntura social, dimensionando o lugar da maternidade e suas nuances nas trajetórias de militância, prisão-tortura e pós-prisão, pode oferecer importantes informações que colaborem para um entendimento mais geral da construção social da identidade feminina e para a construção de uma memória histórica do período.

Trabalhos dessa natureza, ao revelar um cenário pouco explorado nos documentos históricos, apontam:

... como as memórias pessoais dizem não apenas de um passado vivido .... mais também de um fato histórico cujos elementos podem ou não estarem presentes na memória coletiva. Além disso, podem se caracterizar como memórias históricas orais, uma vez que retratam não apenas as vivências de familiares ou militantes, mais de um período histórico no Brasil. (Gianordoli-Nascimento, Veloso, Silva, Cruz \& Oliveira, 2012, p. 3).

Este trabalho baseia-se em memórias pessoais - construídas pela própria pessoa acerca do seu passado, mas que podem envolver fatos sociais vivenciados - e memórias comuns nascidas de fatos e informações guardados por indivíduos que viveram as mesmas situações, mesmo sem estarem reunidos ou as elaborarem conjuntamente - ainda que estas não componham uma memória coletiva do período, o que se faria apenas pela interação entre os indivíduos e a elaboração conjunta sobre o passado. Trabalhamos, portanto, com memórias autobiográficas, isto é, relatos mais extensos registrados no sentido de documentar a título de esclarecimento lembranças de pessoas que desejavam fornecer tais informações (Sá, 2013), memórias que produzem rica contribuição para a memória histórica do período, sendo essenciais para o conhecimento do período por gerações futuras.

Os relatos trabalhados, portanto, apontam o aspecto dinâmico da memória social (Sá, 2013), pois o campo da memória remete a batalhas constantes entre aquilo que é lembrado e esquecido, tendo em vista a permanente negociação entre passado e presente na composição da memória (Pollak, 1989; Sá, 2007).

A escassez de registros históricos sobre a atuação sócio-política feminina sinaliza que na escrita da história não é democrática a experiência de todos os atores sociais envolvidos na dinâmica social. Como salientado por Perrot (2005) o registro oral, bem como, os registros privados são via privilegiada de acesso às memórias das mulheres, tendo em vista que de forma hegemônica a narrativa que predomina na história é a dos fatos públicos registrados e protagonizados por homens. Tratamos, portanto, de memórias de mulheres, ou seja, aquelas invisibilizadas nas leituras oficiais e que ganham corpo na oralidade (Perrot, 2005), no registro transmitido sobre a esfera privada, que neste momento da história do Brasil encontrava-se 
permeada por mudanças politicas, mas também por mudanças nos costumes que marcam os lugares socialmente ocupados por homens e mulheres.

\section{Maternidade e Militância: ou isto ou aquilo}

A imagem da mulher está sócio-historicamente associada à maternidade, já que sua feminilidade se vincula ao aparato biológico ao envolver seu ciclo reprodutivo. Nesse sentido, há uma naturalização da maternidade como fator constitutivo da identidade feminina, reforçada pelo que se convencionou chamar de instinto materno (Badinter, 1985), elemento amplamente valorizado nas representações sociais da mulher na sociedade moderna.

Segundo Badinter (1985) a crença no amor materno instintivo é fruto de um processo histórico-social construído e reforçado na medida em que as mulheres são reconhecidas e valorizadas pelos atributos que a fazem 'aptas' ao exercício materno, e quando ausentes estas características, são consideradas relapsas ou mães más.

Esse sentimento pode existir ou não existir; ser e desaparecer. Mostra-se forte ou frágil. Preferir um filho ou entregar-se a todos. Tudo depende da mãe, de sua história e da História. Não, não há uma lei universal nessa matéria, que escapa ao determinismo natural. $\mathrm{O}$ amor materno não é inerente às mulheres. É "adicional" (Badinter, 1985, p. 366).

A divisão sexual dos espaços sociais provocou a total entrega da mulher aos filhos e à esfera doméstica. O homem, por sua vez, continuou exercendo atividades ligadas aos seus atributos identitários, atuando no âmbito público do mundo do trabalho, a fim de garantir sua função de provedor financeiro. Isto, porém, o afastou do universo do lar, tolhendo-o do exercício da paternidade, por meio da ausência do contato e cuidado dos filhos (Badinter, 1985; Trindade, 1998). As concepções naturalizadas de que os homens não teriam habilidades suficientes para cuidar, sustentavam essas tradições. Assim, maternidade e paternidade também se constituem como construções sociais (Trindade, 1998).

Rompendo com essa configuração, ser mulher e ser militante exigia das mulheres algumas decisões que impunham renúncias dolorosas e com altos custos sociais quanto a suas relações com seus grupos de pertenças, já que suas identidades sociais se construíram por meio do amálgama formado pelo pleno exercício da mulher-mãe. Implicações estas que não se colocavam para os homens, visto que suas identidades, relacionadas ao exercício da paternidade, não se estabeleceram socialmente (Gianordoli-Nascimento et al., 2012).

Ter que decidir entre a militância e o exercício da maternidade indica que a mulher militante estava em um lugar impróprio, pois o lugar da mãe seria no seio da família, no recôndito privado, e não nas ruas e na política. Assim, ser militante se torna sinônimo de ser transgressora, ao manchar a identidade da mulher mãe-esposa (Ridenti, 1990).

Desse modo, ser militante marca a trajetória de “... mulheres que não puderam ter filhos ou os tiveram na clandestinidade, na mais absoluta precariedade e solidão, mulheres que foram obrigadas a se separar de seus filhos" (Goldenberg, 1997, p. 361) e que, até no presente, sofrem as vicissitudes desta condição. A vivência da maternidade, no período ditatorial ou na atualidade, estabelece, contraditoriamente, uma difícil decisão para a mulher por sua condição: ou será isto, ou aquilo. 


\section{Metodologia}

Trata-se de uma pesquisa qualitativa de caráter exploratório que apresenta os relatos de militantes sobre sua experiência de conjugação entre maternidade e militância. Este estudo foi composto por quatro (04) entrevistas realizadas com mulheres que participaram de organizações políticas clandestinas e militaram em oposição ao regime ditatorial, durante o período da ditadura militar no Brasil (1964-1985), e que nesta época engravidaram, conceberam ou tiveram a gravidez interrompida.

A coleta de dados se deu por meio de entrevistas realizadas de forma individual, seguindo-se um roteiro de entrevista semiestruturado composto de duas partes: I) caracterização das entrevistadas na época de militância e no período atual (idade, escolarização, estado civil, tempo de militância, número de filhos, etc.); II) temáticas relacionadas às experiências de maternidade antes, durante e depois da militância.

As entrevistas foram realizadas nos estados de moradia atual das entrevistadas: duas (02) coletadas no Estado de São Paulo, uma (01) em Minas Gerais e uma (01) em Brasília. O tempo médio de duração foi de três a doze horas, conforme a disponibilidade das entrevistadas. Todas as entrevistas foram gravadas em fitas cassetes e em formato digital MP3, após a assinatura do termo de consentimento livre e esclarecido, aprovado pelo Comitê de Ética em Pesquisa da UFMG (COEP), sob o número 0633.0.203.000-09.

Posteriormente as entrevistas foram submetidas à análise de conteúdo seguindo as orientações de Bardin (2009) e Minayo (2010), e enquadra-se no que se chama de análise temática. A análise foi composta pelas seguintes etapas: 1) transcrição dos dados brutos que permite a "pré-análise" (leitura exploratória, leitura flutuante); 2) criação de categorias; 3) separação do conteúdo a partir das categorias criadas; 4) composição de "inferências e interpretação dos dados" (Bardin, 2009, p. 121).

A partir da identificação das unidades de análise, foi possível realizar a categorização das respostas que serviram de prisma para organizar, analisar e interpretar o conjunto de dados obtidos. Posteriormente, estas categorias foram organizadas em eixos temáticos que estavam interligados em seus sentidos e conteúdos, considerando-se, para isso, o cenário sócio-histórico e as experiências com as quais se articulavam. A análise e interpretação dos dados encontramse embasadas em produções científicas que articulam as dimensões de gênero e militância, que serão fontes para a compreensão mais ampla do fenômeno da maternidade vivenciada por mulheres que militaram contra a ditadura militar no Brasil, problematizando aspectos ainda pouco priorizados nos estudos deste período histórico.

\section{Resultados e discussão}

A tabela 1 refere-se aos dados de caracterização das participantes no período de sua militância ${ }^{9}$. As mulheres entrevistadas tiveram inserções políticas diversificadas, sendo que a

\footnotetext{
${ }^{9}$ As organizações políticas de militância, bem como os locais de prisão foram citadas por meio de siglas a fim de se adequar as tabelas 1 e 2, seguem em ordem citada: Ação Popular (AP); Partido Comunista do Brasil (PCdoB); Partido do Movimento Democrático Brasileiro (PMDB); Partido Comunista Brasileiro (PCB); Partido Comunista Brasileiro Revolucionário (PCBR); Movimento Nacionalista Revolucionário (MNR); Vanguarda Popular Revolucionária (VPR); Rede Democrática (REDE); Ação Libertadora Nacional (ANL).Locais de prisão: Departamento de Ordem Política e Social (DOPS) de Belo Horizonte (BH); Operação
} 
idade de entrada na militância variou entre 15 e 20 anos. Todas passaram por experiências de clandestinidade, prisão e tortura quando tinham entre 23 e 27 anos. Em relação à origem, três das entrevistadas nasceram em cidades interioranas, e uma em uma capital. Quanto à classe social, durante a ditadura, houve variação, sendo duas de classe média e duas de classe baixa.

Antes e após as prisões, as participantes viveram períodos de clandestinidade, grávidas ou com filhos ainda bebês. Considerando que algumas mulheres vivenciaram experiências de partos e gravidezes em momentos diferenciados nas trajetórias pessoais de cada uma, podemos observar algumas semelhanças nas vivencias da clandestinidade, exílio e prisão. Além disso, algumas mulheres tiveram mais de uma gestação, o que também reserva singularidades em relação as outras experiências da própria militante. Das oito gestações relatadas, seis se deram em contextos de clandestinidade, sejam elas antes da prisão (duas delas durante a guerrilha rural ou urbana), após a soltura ou no exílio. Apenas duas gestações ocorreram em contextos de pós-soltura ou pós-exílio. Assim, todas descobriram pelo menos a primeira gravidez já na clandestinidade. Em relação aos partos, dos oito relatos quatro foram em contextos de clandestinidade, dois na prisão e dois na pós-soltura ou pós-exílio. Seus partos foram realizados em hospitais, seja em instalações para as quais foram levadas durante o período de prisão, ou com o auxílio de médicos ou profissionais de saúde que conheciam e agiram clandestinamente, ou em hospitais regulares após o exílio ou soltura. Na tabela 2 estão identificados os dados referentes às gravidezes e aos partos. Apenas uma das entrevistadas relatou uma interrupção da gravidez.

Tabela 1 - Caracterização de aspectos políticos das entrevistadas.

\begin{tabular}{|c|c|c|c|c|c|c|c|c|}
\hline \multirow{2}{*}{$\begin{array}{l}\text { Nome } \\
\text { Fictício }\end{array}$} & \multicolumn{2}{|c|}{$\begin{array}{c}\text { Dados de } \\
\text { Nascimento }\end{array}$} & \multirow{2}{*}{$\begin{array}{l}\text { Idade de } \\
\text { Entrada na } \\
\text { militância } \\
\text { organizada }\end{array}$} & \multirow{2}{*}{$\begin{array}{l}\text { Organização } \\
\text { de Militância }\end{array}$} & \multirow{2}{*}{$\begin{array}{c}\text { Duração } \\
\text { da } \\
\text { Militância }\end{array}$} & \multicolumn{3}{|c|}{ Prisão } \\
\hline & Ano & Local & & & & Ano & Local & Tempo \\
\hline Mariana & 1944 & $\begin{array}{l}\text { Interior - } \\
\text { MG }\end{array}$ & 20 anos & $\begin{array}{l}\text { AP/PCdoB/ } \\
\text { PMDB }\end{array}$ & $1964-1980$ & 1969 & $\begin{array}{c}\text { DOPS/BH } \\
\text { Penitenciária } \\
\text { Feminina em Juiz de } \\
\text { Fora/MG }\end{array}$ & $\begin{array}{l}1 \text { ano e } \\
3 \text { meses }\end{array}$ \\
\hline Sílvia & 1945 & Interior - ES & 16 anos & PCB/PCBR & 1961-1973 & 1972 & $\begin{array}{c}\text { Presídio Comum no } \\
\text { Uruguai }\end{array}$ & $\begin{array}{l}\text { 10- } 24 \mathrm{hs} \\
\text { 2ㅇ- } 7 \text { dias }\end{array}$ \\
\hline Sofia & 1946 & Interior - SP & 15 anos & PCB/PCdoB & 1961-1979 & 1972 & $\begin{array}{c}\text { OBAN/SP, } \\
\text { DOI-CODI/DF, } \\
\text { Hospital de } \\
\text { Guarnição do } \\
\text { Exército de Brasília }\end{array}$ & 5 meses \\
\hline Suely & 1949 & Capital - RS & 16 anos & $\begin{array}{l}\text { MNR/VPR/ } \\
\text { REDE/ALN }\end{array}$ & $1965-1973$ & 1972 & $\begin{array}{c}\text { DOPS/SP, OBAN/SP, } \\
\text { Hospital do Exército } \\
\text { em SP. }\end{array}$ & 3 meses \\
\hline
\end{tabular}

Bandeirantes (OBAN) em São Paulo (SP); Destacamento de Operações de Informações - Centro de Operações de Defesa Interna (DOI-CODI). 
Cruz, J. P. D., Gianordoli-Nascimento, I. F., Oliveira, F. C., Santos, T. L. A., Mendes, B. G., Freitas, J. C., \& Reis, D. B.

Tabela 2 - Caracterização das entrevistadas conforme a situação de gravidez/parto.

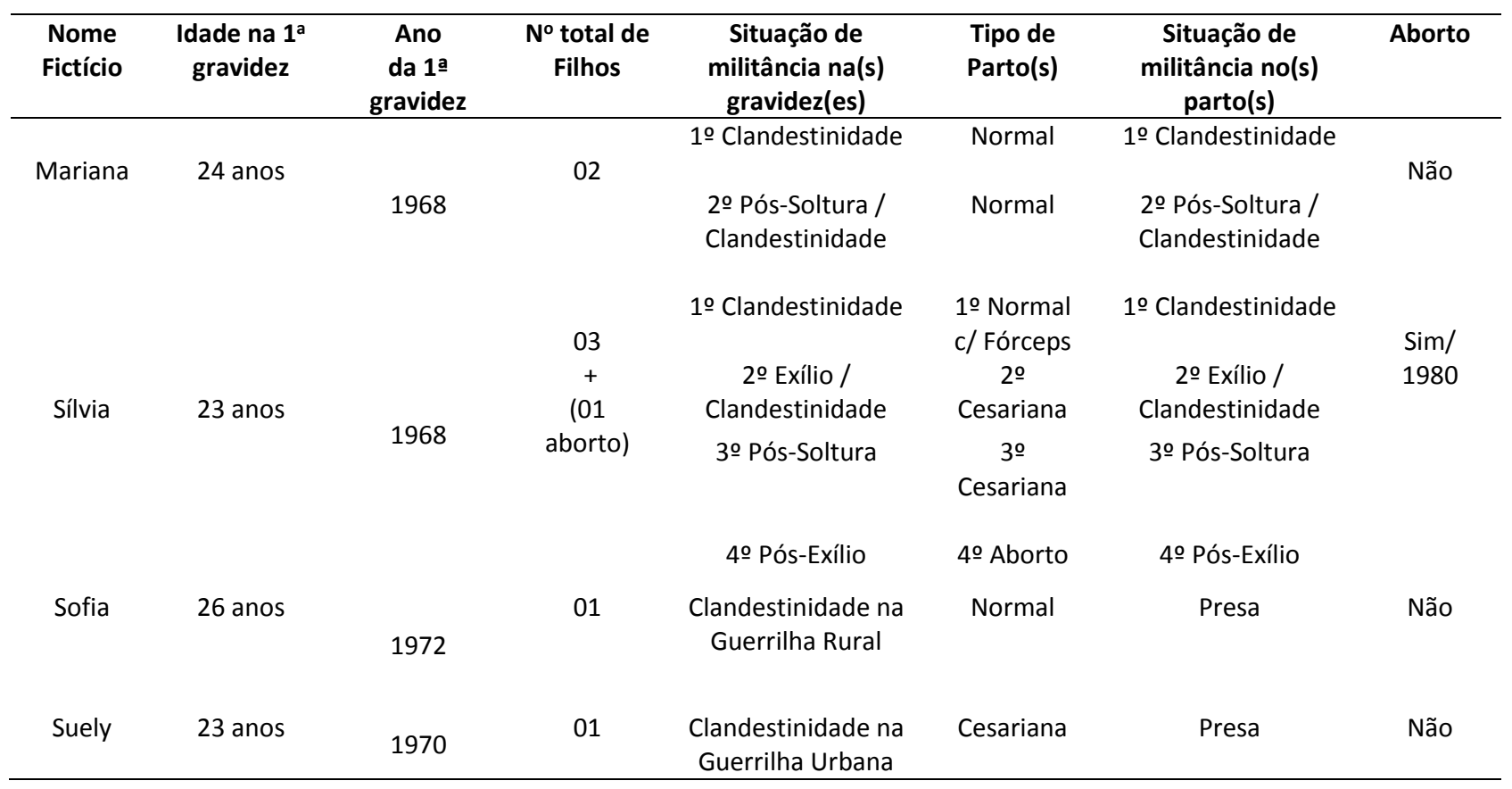

\section{Maternidade e Militância: compreendendo as tensões entre o individual e o coletivo}

Parece-nos que a experiência das mulheres entrevistadas, envolvendo a participação no exercício político, associado ao aumento da escolarização e à profissionalização, introduz, na construção de suas identidades de gênero, a dimensão da participação pública. São dimensões sociais que atualmente se consolidam, principalmente, por meio do trabalho feminino, contribuindo para a ampliação da configuração da identidade da mulher, antes associada apenas ao casamento e à maternidade. Embora ainda se mantenha uma hierarquia entre esses elementos, esta ampliação coaduna com a visão de Carson (1995), na qual a identidade feminina é constituída por três pilares fundamentais:

1) A maternidade e o ser mãe. 2) O matrimônio ou a união e o ser esposa ou companheira. 3) $O$ trabalho ou a profissão e o ser trabalhadora ou profissional. A identidade de gênero das mulheres em um tempo e em um espaço historicamente determinados é produto da articulação específica desses três eixos (p. 209).

Segundo o autor, estes eixos conceituais não se tornam elementos estruturadores da identidade somente por meio da consolidação empírica. Atuam, então, como símbolos que se organizam, desenvolvem e adquirem relevância diferente ao longo da vida de cada mulher. Em função da maneira que a articulação entre eles se recompõe e se reacomoda, produz contínuas transformações a partir de pertenças grupais e sociais das mulheres

...e perdura do nascimento até a morte. .... Eles estão sempre presentes, porque são formas sociais que orientam a conduta, perfilam e valorizam as formas de atuação e, dessa maneira, participam da definição do que é 'próprio' do gênero feminino. Nesse sentido, eles participam como símbolos que descrevem e designam, organizam e acomodam, nomeiam e qualificam detalhadamente o que significa ser mulher. .... Não há uma etapa na qual as mulheres finalizam o processo de consolidação da sua identidade de gênero. O que pode ser pensado através de etapas não é a resolução, mas as 
modificações que a identidade sofre em função das experiências que cada mulher vive, incorpora, valoriza, simboliza (Carson, 1995, pp. 210-211).

Compreendemos, portanto, que a definição dos lugares sociais ocupados por homens e mulheres foi construída ao longo dos séculos, não sendo diferente em termos da construção social da maternidade ou do ideal de amor materno (Badinter, 1985; Trindade, 1998), ideia fortalecida por discursos biologizantes que circulam em nossa sociedade, definindo práticas, e sendo propagados pela mídia e nas conversações cotidianas.

As transformações e o clima de mudanças a partir dos anos de 1960, associados à progressiva entrada das mulheres de classe média nas universidades e no mercado de trabalho, alteraram essa dinâmica. Diferente do que era disponibilizado na geração de suas mães, estas mulheres puderam transitar entre o espaço público e privado, a partir da sua inserção em diversas dimensões da vida pública. No caso específico das mulheres militantes, vemos a importância de sua formação sociopolítica, e, neste ponto, a inserção no mundo da militância pode-se comparar a inserção atual no mundo do trabalho, tendo em vista que isso representava a ocupação de um espaço público, fora do restrito espaço doméstico do lar. A partir de seus relatos, vislumbra-se a difícil tarefa que tiveram em conjugar maternidade, relação afetiva com seus companheiros e a vida na militância.

No período anterior a promulgação do Al-5, as mulheres entrevistadas adentravam para a militância política organizada e já não estavam mais sobre a tutela dos pais. Neste cenário, todas conheceram seus companheiros afetivos, com quem posteriormente tiveram filhos, não necessariamente por meio do casamento. Neste sentido, estavam diferenciando-se do modelo de feminilidade estabelecido na época; por isso, algumas delas, como nossas entrevistadas, Mariana e Sofia, destacaram que foram comparadas, ou assumiram posturas tidas como masculinizadas, o que facilitava serem aceitas entre os seus pares. Embora os jovens contestassem os valores tradicionais e a ordem instalada, no que tange as diferenças de gênero, Sofia relatou os embates com alguns homens, também militantes, em relação às suas tarefas, ponderando os riscos que corria em algumas ações noturnas por ser mulher. Destacou ter se trajado como homem para sentir-se segura, principalmente durante as madrugadas, horário em que a presença de mulheres nas ruas significava estar disponível à prostituição e expostas à violência:

E o [companheiro de militância disse]: 'mas você não é uma mulher emancipada?' [ela responde]'eu sou! Mas o mundo não é. E eu tô no mundo... tá certo?! Não adianta!. Vocês num são homens emancipados? Fala com a mãe de vocês que sua amiga vai ficar na sua casa com você até duas horas da manhã!'. (Sofia)

Colling (1997) afirma que para assumirem um lugar dentro das organizações de esquerda, as mulheres precisaram negociar dimensões de sua condição feminina. "Por serem espaços fundamentalmente masculinos, as mulheres se impunham à negação de sua sexualidade, para conquistarem um lugar de igualdade ao lado dos homens... Os homens militantes, em contrapartida, viam as companheiras militantes como mulheres sexuadas" (p. 117). Nesse sentido, esse olhar para as militantes como mulheres 'diferentes', se relacionava a comparação entre o modelo feminino de referência da época, 'mulher para casar', e o comportamento adotado pelas militantes. 
Os meninos meus colegas morriam de medo de mim, (risos) falavam que eles nunca casariam comigo, que eu era uma mulher muito esquisita! Muito diferente! .... mas era o fato de que enfrentava polícia, era o fato de que eu ia nas reuniões clandestinas até de madrugada ...tinha atitudes, ações, posturas, que na época eram considerados atributos unicamente masculinos! Não eram atributos femininos! A mulher era pra ser mais tímida, a mulher era pra ser mais meiga, mais submissa, né, mais medrosa, certo. Características de capacidade de direção, coragem,... isso era masculino!... (Mariana)

A problematização e a interpretação das entrevistadas acerca das estratégias de ocupação do espaço público/político das mulheres que militaram, no que se refere a posturas que eram distanciadas do feminino, compõem uma leitura atual possibilitada somente pelo distanciamento que o tempo produz. Isso se dá no âmbito da memória na medida em que as transformações observadas e vividas no campo social, em relação à presença feminina protagonizada por essas mulheres, redefinem suas identidades em relação ao "ser mulher militante" (Gianordoli-Nascimento, Trindade \& Santos, 2007, p. 7). Portanto, vale enfatizar que, no momento dos acontecimentos, a tônica era contestar o regime. Somente no processo de construção da memória social por meio das memórias pessoais e comuns, as questões de gênero ganham relevância, articulando novos significados para suas experiências pessoais/privadas (casamento-maternidade) e coletivas/públicas (militância política).

Neste sentido, ainda que as memórias pessoais sejam aquelas relacionadas às experiências de vida das pessoas em determinado contexto e apesar de serem particulares, não são individuais, por serem por meio da linguagem, construídas socialmente (Sá, 2013). Este elemento já presente em Halbwachs (1990) postula que nenhuma memória é individual, há um elemento social no registro da lembrança intrínseco a comunicação. Tais aspectos ficam evidentes nos relatos acima por meio de seleção de temas e acontecimentos que abarcam a percepção de uma leitura/linguagem crítica das relações de gênero entre os militantes homens e mulheres, que em geral, não estava presente na dinâmica dos acontecimentos no momento no qual se davam, mas que foram problematizados anos depois pelos movimentos feministas pós anos 1970 e compartilhados pelas mulheres que atuaram na militância política no período.

Desta maneira, ainda que nossas participantes não tenham entre si a oportunidade de compartilhar experiências, a leitura de seus relatos revela claramente a presença de memórias comuns, que enfatizam acontecimentos e análises relacionadas às experiências vivenciadas no mesmo período e contexto que guardam entre si semelhança em suas narrativas sobre a temática da maternidade em contexto de clandestinidade, prisão, o exílio.

A vida e trajetória das (os) militantes foram totalmente modificadas pela conjuntura sóciopolítica e pelas ambiguidades entre o que era permitido e o que era proibido no âmbito privado e no âmbito social (Almeida \& Weis, 1997; Gianordoli-Nascimento et al., 2012). Assim, as organizações reforçavam as regras de segurança individual e coletiva, estabelecendo normas de conduta e comportamento na vida clandestina de militância. Almeida e Weis (1997) apontam que nesta condição, era preciso aprender a viver aparentando certa regularidade no que tange os códigos e modelos sociais vigentes "... talvez o aspecto mais difícil da condição de clandestino, era construir um cenário de normalidade" (p. 378).

Suely e seu companheiro afetivo, também militante, ao passarem a viver juntos, na mesma casa sem estarem oficialmente casados, simulavam a condição social de "casal recémcasado" como fachada para os vizinhos da casa onde residiam, já que o local era um 'aparelho' 
do partido onde aconteciam reuniões políticas e funcionava uma gráfica clandestina, servindo de esconderijo para outros militantes que estavam sendo perseguidos. Ela, grávida, frequentava esporadicamente a casa dos vizinhos para demonstrar que viviam uma vida "normal" como qualquer casal, mas sem aprofundar nas relações. Assim, o exercício da política que esteve anteriormente a 'todo vapor' nas ruas, nos movimentos sociais, nos sindicatos com as greves, nos debates públicos permeados pela imprensa, foram interiorizados e exercidos na vida privada. As casas, ou aparelhos, que serviam de moradia, além de serem o lugar de se fazer e desenvolver ações políticas, eram também o único espaço de convivência e relação social/pessoal possível entre os militantes. Estas práticas se faziam necessárias na medida em que as representações que circulavam na sociedade, deveriam ser sustentadas com objetivo não levantar suspeitas, assim ao agirem da forma socialmente esperada sustentavam as representações tradicionais de casamento e da própria maternidade mantendo a estabilidade no convívio social.

As quatro entrevistadas (Mariana, Sílvia, Sofia e Suely), se descobriram grávidas em pleno acirramento das forças repressivas do Estado e tiveram a primeira gravidez nesta situação de clandestinidade, apresentando, assim, memórias comuns destas experiências. Para Mariana, Sílvia e Sofia, descobrir-se grávida foi um "susto" e não uma "surpresa", já que nenhuma delas concebia a possibilidade de ter um filho naquele contexto, mesmo que em meio à intensidade das relações amorosas que relatam terem vivido com seus parceiros afetivos. Partindo das construções sociais de gênero, no que tange a maternidade e paternidade (Trindade, 1998), as mulheres dimensionavam de maneira diferente dos homens, o impacto da gravidez e do nascimento de uma criança.

Silvia relatou que seu companheiro afetivo já havia se referido à possibilidade/desejo de terem um filho, mas ela foi contrária considerando o contexto de militância perigoso e levando em conta, também, à falta de contato com os familiares e ao isolamento:

ao mesmo tempo que a gente tava fazendo planificação para sair, para nos incorporarmos a algum foco rural, ele falava em ter filhos. Eu dizia: '[...], não tem sentido! Como é que nós vamos fazer uma vida de luta armada, de clandestinidade e ter filhos?' ele dizia: 'a gente dá um jeito!'. E foi uma loucura, uma loucura!... (Silvia)

Mariana e Sofia, relatam memórias comuns acerca da desigualdade existente entre as responsabilidades envolvidas na paternidade e na maternidade, enfatizando a situação de conflito entre dar continuidade á militância ou viver integralmente a maternidade:

...por causa de filho, quem abandonaria era a mulher... como sempre, é claro! Mesmo hoje... não tá na ditadura. Mas se você tem filho, por mais cabeça aberta que seja o teu marido, a... vamos dizer, a responsabilidade da criança é dez mil vezes mais sua do que dele! Entendeu? Vai afetar dez mil vezes mais a sua vida do que a dele... Então, ah... você tem que ter muito mais força e descobrir [mais] formas [de conjugar inserções], muito mais do que os homens numa situação de ter filhos. (Mariana)

Embora estes casais rompessem com elementos que caracterizam as representações tradicionais e os lugares de gênero no casamento, viviam os conflitos permeados por essa conjugação de valores. Sofia refletiu como a maternidade relacionada à conjugalidade, na condição de clandestinidade e guerrilha, teve dimensões diferentes para ela e para seu companheiro afetivo, estabelecendo conflitos no momento da descoberta da gravidez. É interessante notar que em um contexto tradicional de relações amorosas, apoiado nos 
referenciais do "amor romântico", a postura do parceiro afetivo em desejar a gravidez pode ser interpretada pelas mulheres como atitudes que espelham romantismo e prova de amor. No entanto, para as nossas entrevistadas, que não partilhavam e nem viviam cotidianamente relações amorosas prescritas, o posicionamento dos companheiros afetivos não era interpretado por meio destas representações:

Porque pra um homem é tranquilo ter um filho né? Quando ele descobriu que eu estava grávida até arranjou um nome para ele. Ele tem o nome que o pai escolheu. Agora, para ele [referindo-se ao parceiro] era mais tranquilo, tipo: 'não, você tem o filho, não é problema.' Agora para mim, eu ficava assim: 'um filho vai me prender...' Tanto que eu vim para cá, tive o filho e ele ficou lá, né?! [no Araguaia] Pro homem é mais fácil do que para a mulher... o filho não separa da gente com o cordão umbilical, ele dura mais tempo, né?! Então, eu... por isso que eu tinha essa... contradição! Ter o filho ou não ter o filho?! Entendeu?! Porque isso me incomodava. (Sofia)

O conflito aparece na situação de militância justamente pelo fato de que o modelo de maternidade hegemônico preconizava a dedicação exclusiva da mulher aos filhos, sendo esta a principal e mais importante atuação feminina internalizada pelas mulheres. Neste período histórico, se impunha a elas o exercício materno em detrimento de qualquer outra participação social, que só podia ser exercida enquanto a maternidade não se colocava (Bassanezi, 2004). Um dos pontos que chama atenção no relato das militantes é que, embora a maternidade implicasse na exclusão do exercício político expressado pela conflituosa decisão de se viver "ou isto ou aquilo", algumas vezes apresentada por parte do companheiro afetivo e/ou das organizações políticas, o conflito para elas não se dava em termos representacionais, no que se refere ao "mito do amor materno" (Badinter, 1985), mas em termos instrumentais no que tange a articulação de conjugar exercício materno, nas condições impostas socialmente, e o exercício político, nas condições impostas pelo regime militar. O que estava em jogo para estas mulheres não era a maternidade como elemento da identidade feminina, mas como elas poderiam vivenciá-la naquele contexto.

Diante deste conflito, Mariana exemplificou seu posicionamento na gravidez:

E eu me lembro que eu conversei com um companheiro de militância que era da direção de AP ainda, antes de... do $P C d o B$, e ele falando comigo que, eu tinha que escolher: ou a luta, ou o filho. E aí eu falei com ele o seguinte: "Eu vou ter! E eu quero Ihe dizer uma coisa...No dia, que eu falhar como revolucionária, no dia que eu deixar de cumprir minhas tarefas, ou que eu colocar a luta em risco, você tem o direito de falar alguma coisa. Mas enquanto eu não colocar ninguém em risco, não falhar, não deixar de cumprir, não abandonar a luta, você não tem o direito de falar nada! Porque é o meu filho, tá no meu corpo, e no meu corpo quem manda sou eu!" E não é fácil essa escolha!... Isso foi um dirigente, companheiro de luta, que era meu dirigente. E eu o enfrentei mesmo, e aí o [meu companheiro afetivo] se colocou, perfeito: "Se você decidir interromper, eu tô com você! Se você decidir ter, eu tô com você, e nós vamos ter!" Aí eu comuniquei pra ele: "Vou ter!"... "Então, vamos ter!". (Mariana)

Sofia também passou por este conflito. Clandestina na guerrilha do Araguaia, já havia passado por tensões junto aos dirigentes da organização em função da sua união conjugal com um militante guerrilheiro. A descoberta da gravidez e a preparação para falar com a direção trouxeram muitos conflitos para ela, que internamente fazia a avaliação sobre sua trajetória e inserção política:

... agosto de 1972 eu tava grávida, né?! .... [com a perda do contato com militantes] a direção achou que eu devia ir pra São Paulo, porque uma gravidez lá ia ser uma coisa muito difícil, no meio da 
guerrilha. Eu vinha pra cá, fazia o aborto ou tinha o filho e aí via as condições... eu tinha um objetivo na vida, tá certo. E não incluía maternidade naquele momento. (Sofia)

De acordo com Rocha-Coutinho (2009), diante destas contradições, as mulheres é quem são socialmente ensinadas a fazer uma opção: entre o trabalho e a construção de uma carreira profissional ou a pausa na vida para o momento da maternidade, como se não pudessem conjugar a maternidade a outras atividades. Dessa forma, a autora define um modelo tradicional de maternidade, que estaria ligado ao tamanho da prole (nos anos de 1930/40/50) ainda numerosa, sendo a principal função da mulher: ser "boa mãe" e "boa esposa". Estas são exatamente as representações de maternidade a partir das quais as mulheres entrevistadas foram socializadas para cumprir, mas com o qual romperam em alguma medida, abrindo a possibilidade para outros modelos, que não sem ônus, possibilitaram à mulher a conjugação e a ampliação de suas inserções (Vaitsman, 1994). De acordo com Rocha-Coutinho (2009), esta seria a nova mulher moderna, que além de conjugar casamento e trabalho, exerce um novo modelo de maternidade repleto de tensões no que se refere às seguintes decisões: opção de ter ou não filhos; adiar a gravidez em detrimento da carreira; quando e quantos filhos ter. Ainda hoje a decisão de ter ou não ter filhos preocupa as mulheres, mesmo que novos elementos simbólicos venham negociar a possibilidade de não tê-los, diante das representações tradicionais que ainda circulam em nossa sociedade, tal escolha não é sem consequências para as mulheres (Barbosa \& Rocha-Coutinho, 2007, 2009).

Considerando todos os aspectos que abrangem as situações de imposições sociais veladas e simbólicas que envolvem a contínua construção da identidade de gênero feminina, preferimos, analiticamente, considerar que as mulheres revelam memórias comuns de uma 'tomada de decisão conflituosa' na qual se somam sentimentos de incompletude e culpa por terem decidido entre uma coisa ou outra, ou por considerarem as perdas que a sobrecarregaram na conjugação da maternidade e o ser esposa com a carreira/trabalho.

Para os homens, isso não se faz como questão, até porque socialmente não são educados para exercer a paternidade. "Quase como uma decorrência natural dos modelos tradicionais de gênero, o homem adquiriu o privilégio da paternidade voluntária, enquanto a mulher se submete à maternidade obrigatória" (Trindade, 1999, p. 35). Tradicionalmente, eles podem estar apartados do exercício das práticas de cuidado com os filhos, porque sua função principal é a provisão (por meio do trabalho) e não a procriação e o cuidar, considerados atributos identitários femininos. Por outro lado, mesmo quando os exerce, o conflito pessoal/identitário não se instaura quando deixam os filhos para a realização de outras atividades. "Não existem sanções sociais para o homem quando se nega a ter filhos e nem mesmo quando não reconhecem um filho" (Trindade, 1999, p. 35).

Das quatro militantes entrevistadas, Suely é a única que relatou ter desejado e planejado ter um filho aguardando a gravidez, confirmando-a desde o início: "[A gravidez] foi querida, ..., $a$ escolha de ter um filho naquelas circunstâncias num foi acidental, foi procurado, eu quis e ele quis também. É (pausa longa) e... fiquei grávida, foi uma felicidade muito grande pra gente, pra ele." Condição bem diferente das outras mulheres, que se descobriam grávidas depois de alguns meses de gestação (entre dois e quatro meses) por meio do atraso menstrual consecutivo, sem a possibilidade de fazerem um exame que comprovasse a gravidez, significando também que não sabiam com segurança o tempo que tinham de gestação. Mariana revelou que só soube 
que estava grávida de gêmeos, e com sete meses de gestação, no momento em que foi atendida clandestinamente em condição de urgência em um hospital, em trabalho de parto prematuro.

Os relatos revelam memórias comuns de como estas mulheres, apesar de viveram condições extremas e diferenciadas diante do embate político, ainda assim, buscaram se dedicar em cumprir o papel de mãe conforme foram socializadas. Essas militantes tiveram que conjugar a maternidade com a vida política em um contexto de perseguição e ameaça, na qual a vida pública passou a ser exercida de forma privada e clandestina, vivendo de forma "paralela" a realidade (Pietrocolla, 1996; Gianordoli-Nascimento et al., 2012). Neste contexto, as militantes foram induzidas, por suas inserções e trajetórias na militância, a viver o que era possível em uma situação limite: "Na verdade... as possibilidades de escolha que eu tive na vida, foram poucas." (Silvia).

\section{Nascendo nos porões da ditadura: gerando vida em um contexto de morte}

As memórias pessoais e comuns sobre a maternidade das militantes que tiveram seus filhos nos figurados 'porões da ditadura' (Almeida \& Weis, 1997; Gianordoli-Nascimento et al., 2012) carregam, no que se remete ao parto, aspectos que na atualidade podem ser inimagináveis.

As diferentes vivências das militantes em relação à gravidez e ao parto em situação de clandestinidade, prisão, pós-soltura e exílio trouxeram um novo significado a experiência de maternidade das mulheres nesse contexto. Esta questão, além de abordada no momento da entrevista, ganhou relevância a partir da análise dos resultados quando identificamos que de forma compartilhada os partos aconteceram em ambientes e situações incomuns, cercados de sentimentos como de medo e iminência de morte, além do temor sobre o que poderia acontecer posteriormente com seus filhos, elementos ricamente marcados nos relatos orais. " $\mathrm{A}$ tensão, medo/culpa das mulheres irá aparecer constantemente no relato de seu contato com a repressão" (Colling, 1997, p. 78).

$\mathrm{Na}$ época em que nossas entrevistadas estavam grávidas e foram parturientes, não tiveram a oportunidade de viverem "um misto de ansiedade e alegria" ao terem seus bebês nos braços e confirmarem a expectativa de que estavam saudáveis (Sarmento \& Setúbal, 2003, p. 264), diferente da maior parte das mulheres no momento do parto. A preocupação dessas militantes era em relação à sobrevivência do bebê diante de um regime autoritário que as perseguia. As entrevistadas Suely e Sofia, passaram parte de suas gestações no cárcere, relatando de forma comum que, durante a prisão, o sentimento que mais as tomavam era o de medo ao darem à luz:

... imagina uma mãe gerenciar a prisão dela, a militância dela... E saber que de um momento pra outro podia acontecer da polícia levar os filhos na frente dela, para ser torturado, entendeu? .... o maior drama duma mãe é: ou você tá parindo um filho e ter medo que desapareçam com teu filho; ou então, esse negócio de você ver maltratar teu filho. Eu não digo nem torturar, maltratar! ... Que já maltratar tem um significado muito mais restrito, entendeu? .... e as crianças foram maltratadas $e$ foram praticamente torturadas, quer dizer, tinha criança que apanhava, tinha criança que era humilhada. Porque torturar seria o máximo da perversidade humana! (Suely) 
Estes sentimentos fizeram do momento do parto um momento de ambiguidade e conflitos para as mulheres, principalmente para Sofia e Suely, que foram presas com aproximadamente seis meses de gravidez e deram à luz em hospitais militares em um clima de tensão e pavor que não apenas as colocava em insegurança, mas também seus filhos, que estavam prestes a nascer:

[na hora do parto] aí veio essa questão de novo, a contradição... queria ter meu filho, sabia que eu tinha que ter, mas falei assim: "A hora que me separar dele, vai ser pra sempre, os caras vão levar ele." Então, isso me deu muita dor, porque eu tinha contração e eu fazia força pra sair e fazia força pra voltar, eu fazia tudo, entende?! E tinha consciência que eu tava fazendo tudo isso. Pra mim tava claro, o que me passava... "Olha cê tá separando do seu filho ... ai eu fazia força pra voltar.". (Sofia)

Da mesma forma, as memórias revelam de forma comum, lembranças ambíguas no que se refere a gravidez como elemento que fragiliza, mas capaz de proteger. A proteção favorecida pela situação de gravidez se relacionava à intensidade e às formas de torturas perpetradas contra as militantes. Desta forma, elas consideraram que o fato de estarem grávidas as protegeu da morte, apesar de não as livrarem das sevícias e da violência da tortura:

... a gravidez, ... de um lado, ela pode incomodar o torturador, porque limita ele, ... porque a barriga ia crescendo muito, ...eles só não faziam as mesmas torturas que faziam nas outras mulheres, tipo, choque elétrico na vagina e não sei o que... Mas choque elétrico nos pés e nas mãos eles davam. Era muito espancamento, principalmente com palmatória nas mãos e nas solas dos pés. E... no rosto, né?! Soco, tapa, murro na cabeça, sabe?!... E ameaça de morte, né?, eles ameaçavam de matar o bebê, ameaçavam de... de me matar... E isso era o tempo todo ... [tinha também] tortura do tipo... do isolamento... né?!. Te levar pra uma sala de interrogatório, não te interrogar e te deixava lá horas, sem comer e sem beber... (Sofia)

....faziam dez horas de interrogatório numa mulher grávida, não importa em que condições... Isso por si mesmo já é um crime! E não podia sentar naquela hora e nem podia cair. Exercício de segurar a barriga, Isso que eles me diziam. (Pausa) E as veias me lastravam nas pernas... (Pausa) com as pancadas que eu recebia entre perna e costa e tudo mais! Não dá gente! Cinco, seis homens tratam uma mulher na prisão dessa maneira, grávida! (Suely)

Sofia ressaltou, ainda, que além das torturas psicológicas cometidas contra ela, os conflitos passados dentro da prisão em relação à luta pela sobrevivência dela e de seu filho causavam uma situação de tensão, em que os próprios pensamentos a castigava, o que nos permite compreender que uma das funções da tortura cumpria seu papel, a sua internalização:

O tempo todo era esse negócio... [eu pensava]: 'ganhei um dia, já que hoje eles tiveram um contratempo, ganhei um dia! É... Quantos dias eu consigo ganhar? Não sei quantos, mas eu vou morrer...'. Então você fica naquela: 'mas será que meu filho vai... quê que ele vai achar dessa vida, ele não vai ter mãe... como vai ser...'. Tudo roda na sua cabeça, tudo te tortura. É uma tortura o tempo todo. Quando você não está sendo torturado, essas ideias estão te torturando. E... e era um negócio assim, né... você passa a não ter[futuro]... o seu futuro é o dia seguinte: 'será que eu vou viver amanhã?'. (Sofia)

Chauí (1987), ao nos fazer refletir sobre "a experiência da tortura" (p. 32), aborda que a consequência desta experiência-limite é a destruição do outro enquanto sujeito. Assim, o torturador passa a estabelecer com o torturado uma relação intersubjetiva em que ele, enquanto agente, penetra sua ação no torturado. Daí os relatos trazerem sempre dimensões de resistência, na qual o esforço principal era manter-se lúcido, pensante, articulando estratégias psicológicas. A resistência "é encarada como esforço gigantesco para não perder a lucidez, isto 
é, para não permitir que o torturador penetre na alma, no espírito do torturado .... isto é, não permitir que o torturador se aposse ...de sua subjetividade, de sua humanidade." (Chauí, 1987, p. 34).

Compreende-se, assim, que a condição feminina de ser mulher e militante e a condição materna, isto é, de estar grávida ou de ter tido um filho, foi uma das formas utilizadas pela repressão para torturar as mulheres e para fazê-las se sentirem culpadas por serem comunistas e estarem grávidas, sinalizando o aspecto de que não seriam "boas mães" por fugirem do modelo de mãe e mulher da época. Moralmente eram desvalorizadas por estarem grávidas e não serem oficialmente casadas, consideradas, desta forma, mulheres de conduta imoral. "Para a repressão, a mulher militante será definida sempre como 'puta comunista'" (Colling, 1997, p. 84).

Coimbra (2004), ao tratar a relação entre gênero e tortura, partindo do relato de sua própria experiência, revela e analisa o quanto a tortura perpetrada contra a mulher era severamente e especialmente machista: "Inicialmente são os xingamentos, as palavras ofensivas e de baixo calão ditas agressiva e violentamente como forma de anular a pessoa, o ser humano, a mulher, a companheira e mãe" (p. 54), revelando uma dimensão de violência voltada contra o lugar social da mulher. Sem dúvida alguma, os relatos apresentados despontam a misoginia perpetrada pelos homens, e não só pelos agentes torturadores. Esta dimensão pode ser percebida no que foi contado por Mariana ao dizer que o torturador, observando as cicatrizes recentes da cirurgia pós-parto, tomou tal aspecto como ponto para humilhá-la e desmoralizá-la em sua condição de mãe e mulher, dizendo, sarcasticamente, que estava diante de uma autêntica "puta - que - pariu". Tendo em vista a resistência de Mariana, frente às torturas físicas, sexuais e psicológicas, eles utilizaram da condição materna, especificamente a ameaça de tortura da filha, como estratégia para fazê-la sucumbir.

Era uma coisa, terrível! Eles me diziam: 'não vamos matar ela não! E nem você... Nós vamos quebrar todos os ossinhos dela, vamos derreter, ou torrar os miolos dela, e ela vai virar um monstrinho! E aí sabe o que nós vamos fazer? Nós vamos botar ela no seu braço pra você passar o resto da vida sabendo, que você é a culpada dela ter ficado desse jeito pelo fato de você ser uma mãe comunista, desnaturada, que a culpa é sua!'. Então era, é um negócio terrível!". (Mariana)

O uso da condição feminina para torturar tem, segundo Colling (1997), a função de mostrar como essas mulheres eram desviantes do modelo, duplamente transgressoras (Goldenberg, 1997), porque estavam ocupando um lugar que não era próprio para elas - o mundo da política - e enfrentando e resistindo ao regime opressor (Ferreira, 1996; Colling, 1997; Goldenberg, 1997). Sofia, que ficou presa no DOI-CODI de Brasília, sendo a única mulher naquele período no presídio, refletiu sobre como se sentia em relação aos militares, e como eles se comportavam em relação a ela:

Eu era do exército inimigo, vamos dizer, então eu era um soldado como eles, tá certo?!. E quando eles me viam como igual, ou como mulher grávida, eu acho que eles se sentiam assim, bem diminuídos, porque eles tinham tanto ódio, mais tanto ódio! A fala era de ódio, sabe?! Aliás, o que eles tinham, assim, de ódio de mulher era um negócio impressionante! (Sofia)

Goldenberg (1997) pontua que “... o fato de ser mulher acirrava nos torturadores uma raiva maior [o que despertava] reação de asco em seus torturadores [além] das acusações de desvio a que eram submetidas" (p. 362). 
Se o fato de serem mulheres e estarem naquele contexto já as destoava do modelo esperado, colocando-as como "mulher desviante" (Collling, 1997, p. 80), a condição de maternidade ainda Ihes impunha uma desaprovação maior. O exemplo de uma fala de Suely nos permite pensar como essa disparidade entre o modelo de ser mulher/militante e mãe estava colocado. Suely estava passando por muitos conflitos na prisão e isto se intensificou quando foi informada sobre a morte de seu irmão militante, precisando, assim, ser atendida por um médico:

O médico, me tirou a pressão, não sei o quê... e disse pra mim (pausa breve): 'porque que a senhora foi se enfiar nessa?... Grávida de uma criança foi se enfiar nessa?!' Como se fosse dizendo pra mim: 'A senhora é uma irresponsável, a senhora foi fazer militância, pra depois se enfiar numa dessas. (Suely)

Por elas serem consideradas duplamente transgressoras, os agentes da repressão, e até mesmo os médicos militares, consideravam que o nascimento ou a sobrevivência do filho daquelas mulheres - especificamente os filhos de Sofia e Suely, que estavam grávidas, prestes a dar a luz, e de Mariana, que havia tido uma criança - não valia a pena, porque nasceriam novos comunistas. A partir da análise dos relatos, parece que a gravidez era percebida como uma ameaça para eles, pelo dever que tinham de exterminar os comunistas e o comunismo.

Sofia permaneceu 27 horas em trabalho de parto, tendo sido levada duas vezes ao hospital do exército, onde os médicos se negaram a atender uma comunista e a fazer seu parto. Passou por experiências ambíguas ao pensar que ela e o filho poderiam morrer, mas também pelo fortalecimento em seu desejo de ter aquela criança:

esse era um médico torturador... eu falei assim: "mas meu filho não vai sobreviver", ele falou assim: "ah, não tem importância é um comunista a menos!"... Aí [veio] essa questão de novo, a contradição .... Aí eu fazia força pra ele nascer e tinha aquele negócio [eu pensava]: "não vai ser um comunista a menos, vai nascer! O que vai ser não importa, mas vai nascer..." (Sofia)

Durante o demorado trabalho de parto na prisão, a bolsa de líquido amniótico de Sofia, rompeu-se ainda dentro da cela "Lá tinha milhares de baratas, então elas ficaram assanhadíssimas com o líquido [amniótico], elas subiam na minha perna, querendo entrar na minha xoxota [vagina]". Depois de muito hesitarem em fazer o parto, realizado no Hospital de Guarnição do Exército de Brasília, ela teve um parto de tipo normal, num ambiente totalmente carregado de tensões, em um quarto cercado de militares: "ficava lá o carinha com metralhadora". Como tinha formação incompleta na área da enfermagem, Sofia percebeu que durante e após o parto sofreu dores que, com o procedimento anestésico, poderiam ser poupadas; mas, novamente outras contradições apareciam para ela, por acreditar que ao ser sedada poderiam levar seu filho:

... ele fez a sutura da episiotomia, todinha sem nenhuma anestesia local. Eu sentia a agulha entrando na minha vagina (ashsss), assim... sabe?! Ponto por ponto, aí eu comecei a chocar de dor. A entrar em estado de choque. Comecei a tremer, tremer, tremer, a pressão a cair.

Suely, também presa e levada para um hospital militar, esteve em um ambiente totalmente ameaçador; no seu quarto havia militares durante todo o tempo. Ela teve um parto do tipo cesariana, "Eu não consegui ter dilatação. Eu tive contração de parto, por quase vinte quatro horas, mas não conseguia ter..." Para ela, não ter tido um parto normal foi sua salvação, pois o que mais nos aparece nesses relatos é o medo que essas mulheres tinham de seus filhos não sobreviverem, ou de serem apartadas deles e não os terem em seus braços: 
...minha própria natureza, me impediu que eu estivesse um parto normal. Então cesárea era como se fosse uma garantia a mais .... Porque se eu tivesse tido no parto normal, eu imediatamente poderia ter sido separada dela. Rapidamente, eu poderia ter sido separada dela. O meu medo, o medo que eu vivi dentro daquele hospital, foi o medo de me separar dela. Naquele momento, eu me dei conta que eu ....corria risco com ela. Que ela corria risco, entendeu?! Então eu tinha um medo que essa menina nascesse. Eu fiz uns... uns dez dias, mais ou menos, de greve de fome lá dentro, não comia absolutamente nada, eu não tocava em nada. Eu tinha medo que eles me dessem alguma coisa para abortar. Eu tinha algum medo que... entendeu?! Para antecipar o parto, entendeu? Pra me tirar a criança... (Suely)

Notamos que a experiência do nascimento dos filhos é rica em elementos de memória que são comuns entre as entrevistadas, seja por dados objetivos ou pela mobilização de sentimentos comuns. Mariana também passou por momentos ambíguos na prisão em relação ao que os torturadores poderiam fazer com sua filha. $\mathrm{O}$ que mais lhe afetou psicologicamente, fazendo-a pensar que iria enlouquecer, eram as constantes ameaças de sequestro e tortura de sua filha de três meses:

Eles ficavam me descrevendo, dizendo que eles tavam revistando a casa de todas as minhas colegas do serviço social, e que eles iam pegar minha menina. Ficavam me descrevendo as torturas que iam fazer com ela. Era um negócio terrivel! Nossa senhora! Aquilo pra mim era muito mais pesado do que todas as torturas físicas, do que pau de arara, do que choque elétrico, do que estupro, do que tudo isso .... Era eles ficarem descrevendo o que iam fazer, com minha filha na minha frente. (Mariana)

Tais características não eram exclusivas do regime de exceção brasileiro, visto que, segundo Lozano (2007), nas ditaduras dos anos de 1970, na Argentina, o desaparecimento de crianças, filhas de militantes presos, se tornou uma das principais frentes de luta feminina contra o regime opressor do país: as "abuelas de Plaza de Mayo", um movimento formado por avós que contestavam o desaparecimento de crianças, praticado por meio do aparelho repressivo argentino. Lozano (2007) relata que os desaparecimentos aconteciam principalmente após o parto, sendo uma prática frequente engendrada pelos agentes da ditadura: "Las mujeres parieron en centros clandestinos de represión recibiendo una aténcion médica mínima y sus hijos le fueron arrebatados inmediatamente después del parto" (p. 77). Embora esta seja uma ação com poucos registros conhecidos ou revelados no Brasil, e que, portanto, não compõem a memória histórica do período, as entrevistadas, Mariana e Sofia, relataram memórias pessoais e comuns sobre as ameaças de alguns militares. Sofia se sentiu ameaçada por um oficial militar que, ao conduzi-la para o parto, enfatizou que se nascesse "um menino, branco e saudável" ele o levaria para sua esposa.

Também notamos memórias comuns sobre a ausência de acompanhamento pré-natal (duas em situação de clandestinidade - Mariana e Sílvia / e duas em situação de prisão - Sofia e Suely). No momento do parto tiveram que vivenciar solitariamente a dor física e psicológica, com a pressão do ambiente e o temor de que algo acontecesse aos seus filhos. Suely, por exemplo, reconhecendo que a situação de prisão a impediu de ter uma gravidez como de outras mulheres, ironizou a situação: "Meu pré-natal foi na Operação Bandeirantes ${ }^{10 . "}$

\footnotetext{
${ }^{10}$ Segundo Joffily (2013), a Operação Bandeirante (OBAN) era composta pelas três instâncias das Forças Armadas: Exército, Marinha e Aeronáutica. Sua principal ação era "identificar, localizar e capturar" (p.42) militantes políticos, os considerados "subversivos", a fim de obterem informações sobre as organizações e ações dos grupos de esquerda durante longos interrogatórios e sessões de tortura.
} 
Segundo Scavone (2004), os fatores biológicos da gravidez estão atrelados aos significados sociais. Neste sentido identificamos, por meio dos relatos, que o preparo pré e pós-parto têm importância psicológica e subjetiva para a mãe e é culturalmente valorizado em nossa sociedade, significando atitudes de cuidados, dedicação e responsabilidade por parte da mãe. São práticas as quais essas mulheres não puderam se dedicar devido ao contexto de clandestinidade e também após o nascimento dos filhos por terem sido apartadas destes, como no caso de Sofia e Silvia.

Como já dissemos, a busca por uma consulta médica, ou o acesso a um hospital era avaliado como uma ação de risco, pois precisariam fazer fichas, apresentar documentos, e se expor em diferentes espaços públicos. Para as mulheres vivendo na clandestinidade, a procura por um profissional de saúde ou por um hospital, poderia ser uma forma de entrega de si mesmas para a prisão, colocando em risco a vida de seus companheiros de militância, o que não as isentava da preocupação contínua sobre o bem-estar de seus bebês.

Tais aspectos foram enfatizados também por Gianordoli-Nascimento et al. (2012), quando uma das mulheres por elas entrevistadas relatou a importância e a responsabilidade que sentia, durante e após a prisão, sobre os possíveis impactos negativos no desenvolvimento do seu bebê, devido à sua gestação na prisão. A preocupação em realizar o pré-natal foi um suporte instrumental de grande relevância emocional para essa mulher, significando para ela a segurança de que estava sendo uma boa mãe e a sensação de compensação pelo sofrimento que, como ela acredita, ambos viveram. Nesse sentido, a maternidade pós-soltura representou seu plano de vida e a motivação para retomar seus projetos pessoais de formação e carreira, pois devia continuar vivendo por esse filho e precisava fazer isso sozinha. Dimensões estas também presentes na experiência das mulheres do nosso estudo.

Macedo, Progianti, Vargens, Santos e Silva (2005), a partir de uma abordagem humanizada de parto, ressaltam que estudos apontam para a importância de um ambiente equilibrado para os momentos que antecedem ao parto, já que o ambiente hospitalar em si, a saída do ambiente cotidiano, a falta de familiares, além do peso da construção sociocultural sobre a dor, influencia não apenas na percepção das mulheres em relação ao incômodo sentido durante o parto, mas na própria dificuldade que esses aspectos causam a parturiente e ao bebê. "O relaxamento, a confiança, o repouso, a liberdade de se movimentar, o contato com pessoa amiga, o fato de estar ativa, descansada e alimentada, em ambiente acolhedor, confortável e o mais silencioso possível diminuem a percepção da dor. " (Macedo et al., 2005, p. 307).

Estas recomendações, embora estejam ligadas ao desenvolvimento de estudos recentes sobre o parto humanizado e a influência do ambiente na percepção da dor de mulheres durante o trabalho de parto, nos ajudam a compreender o quanto a situação de prisão, além de todas as suas nuances ligadas à tortura, isolamento e má alimentação, também influenciaram de forma negativa o momento do parto das militantes.

Outro fator ressaltado pela literatura de cunho médico é a importância do aleitamento materno, não apenas nas primeiras horas de vida, onde é essencial para a prevenção de doenças e para fortalecer o contato da mãe com o bebê, mas nos momentos posteriores da vida da criança (Boccoline, Carvalho, Oliveira \& Vasconcellos, 2011). Sofia contou que, ao pedir para ver o filho, foi repreendida pelo médico que disse estar ocupado com o procedimento cirúrgico: 
"Ele nasceu às duas da manhã, foram me mostrar de tarde. Falaram assim: 'não pode amamentar não, porque é vinte e quatro horas em jejum, ele está tomando soro... soro é muito bom!... não deixaram eu amamentar..."

Sofia e o filho permaneceram no hospital por 52 dias, onde o filho era alimentado a base de soro, além de ter sido sedado com tranquilizantes porque chorava muito:

Meu filho nesses cinquenta e dois dias passou por isso tudo! Muita tortura, em muito pouco tempo em uma criança muito pequena! .... Meu filho com um mês estava pesando dois quilos e setecentas, meu filho nasceu com três quilos cento e cinquenta!... (Sofia)

Suely e Silvia também relataram a impossibilidade de amamentarem seus bebês. Silvia, ao ir para o exílio, deixou a filha de dois meses de idade no Brasil, sem tê-la registrado, entrando em profunda depressão, inicialmente por não suportar viver afastada de seu bebê, e, posteriormente, pelo não reconhecimento e exercício da maternidade, chegando a ser internada em clínica psiquiátrica e a tentar suicídio em mais de uma ocasião.

Nestas condições, as redes de solidariedade se fizeram importantes antes, durante, e depois da prisão, já que essas mulheres, distantes de seus familiares, precisaram do suporte de seus amigos militantes e de outras pessoas que se arriscavam ao se disponibilizarem para ajudar. Almeida e Weis (1997) ressaltam que, nas situações de clandestinidade e prisão, “... as mínimas manifestações de solidariedade tinham enorme significado para quem recebia" ( $p$. 392), e nestas situações de solidão, a relação com um outro que reconhece pontos de identificações enquanto ser humano (Souza, 2004) tem suma importância no sentido de tornar uma experiência de medo, abandono e terror, em algo minimamente suportável.

No momento anterior ao parto, ainda no período de gestação, Silvia e Mariana, por exemplo, precisaram contar com o apoio de seus companheiros de militância, pois nunca haviam feito uma consulta médica e estavam prestes a ganhar seus filhos. Até hoje elas se referem de forma agradecida e sensibilizada, à arriscada solidariedade de médicos e /ou profissionais da saúde, parceiros ou conhecidos pessoais de militantes das organizações políticas clandestinas, que as auxiliaram na realização do parto em condições precárias e de risco, dando suporte para que suas crianças pudessem nascer amparadas por um aparato médico e de saúde, o que garantiu a proteção e sobrevivência, delas e de seus filhos.

Mariana e Suely recordam-se de forma comum de terem recebido ajuda de outras mulheres militantes que doaram enxovais para suas crianças: "[Os companheiros do partido foram] ...procurar companheiras que tivessem tido, neném, colegas, ex-colegas minhas, pra pedir roupinha de criança" (Mariana). Suely, mesmo na prisão, experimentou a solidariedade de suas amigas militantes que lhe enviaram, de um presídio no Rio de Janeiro, um enxoval:

[o bebê] não tinha enxoval. Depois chegou um enxoval do Rio de Janeiro, dado por uma mãe de uma companheira que estava presa, mandou para o presídio Tiradentes, do presídio Tiradentes foi dado para mim. Que era o enxoval para 'essa criança' que ia nascer, que todo mundo sabia que não tinha roupa, que tava pelada. (Suely)

Já Sofia, que não se permitia dormir com medo de que seu filho fosse sequestrado, recebeu a solidariedade de um soldado que fazia a vigília em seu quarto, se oferecendo para vigiar seu bebê enquanto ela dormia. Esta atitude significou um caráter humanizante naquela conjuntura ameaçadora, o que de certa forma “...amenizava um pouco a tremenda sensação de 
terror, solidão e desamparo" (Almeida \& Weis, 1997, p. 392). "Ali tinham tipos humanos diferentes." (Sofia).

Com base no trabalho realizado por Bonomo, Trindade, Souza e Coutinho (2008), podemos observar que as ações de solidariedade entre mulheres, principalmente em relação a gravidez, as aproximam no que se refere a sua identidade gênero. É como se elas pudessem compartilhar e compreender sua condição feminina, por serem mulheres, o que, de certa forma, se liga também a ideia do mito do amor materno (Badinter, 1985), no aspecto instintivo.

Estes laços de solidariedade são marcas das memórias pessoais e comuns relatadas pelas militantes. Além disso, tais laços também eram notados no contexto externo a militância, seja pelo auxílio de vizinhos ou pelo suporte dado por familiares, como, por exemplo, durante a infância das crianças, quando as militantes e seus companheiros afetivos precisavam se ausentar para atividades políticas ou de trabalho remunerado:

Tinha sempre vizinhas que a gente tratava pra ficar com as meninas quando a gente saia. Um povo muito legal, muito bom, muito solidário. A gente falava que era pra trabalhar. Então, muitas vezes era, mas muitas vezes era para o trabalho clandestino político... Elas foram criadas sempre com gente boa cuidando delas, né? Eu tive muita sorte! (Mariana)

As mães das militantes também tiveram papel fundamental no momento de pós-soltura, quando retomavam suas vidas conciliando maternidade e trabalho: "Aí eu fui pra casa dos meus pais (...) fui morar lá com as crianças, então eu dividia a tarefa com aminha mãe, eu assumia uma parte e ela dividia comigo o cuidado das crianças..." (Sofia). Além do próprio filho, Sofia ainda cuidava de seus dois sobrinhos, pois sua irmã e cunhado estavam presos. Suely, por exemplo, teve o apoio e suporte da mãe durante os longos anos de exílio.

Mariana, como gesto de gratidão por tudo que os parentes haviam feito para a primeira filha e por ela própria, ao escolher o nome de sua segunda filha, os homenageou: "Eu decidi que, se fosse menino, ia [ter o nome do meu cunhado] e se fosse menina ia [ter o nome da minha irmã]. E independente do significado reais dos nomes, significaria "muito obrigada por terem salvado a [Maria]".

A escolha do nome como forma de homenagem foi elemento que se repetiu nas memórias relatadas pelas entrevistadas. Sofia conta que o próprio companheiro afetivo, ao saber da gravidez, escolheu o nome de um guerrilheiro que era companheiro de ambos, na guerrilha do Araguaia, e que havia morrido em uma ação. O nome da filha de Suely também foi uma homenagem ao pai da criança, militante morto sob tortura antes de conhecê-la. Sílvia, em sua terceira gravidez, já no exílio, homenageou seu médico obstetra: "Eu coloquei o nome nele de (...) porque era o nome do meu ginecologista-obstetra. Ele me dava uma segurança! Eu tava muito grilada...e tinha a história [da morte do segundo filho]... então tinha todos aqueles traumas. " (Sílvia)

Contar com o auxílio de outras pessoas que nem sempre eram militantes, mas se simpatizavam com a causa, inclusive médicos e até mesmo soldados (Almeida \& Weis, 1997), teve grande relevância na vida dessas mulheres, que se recordam e se sentem imensamente gratas pela ajuda dessas pessoas:

Eu sou vitoriosa e realizada pessoalmente, entendeu? Pela amizade, pela solidariedade, que eu descobri no povo do Brasil afora, entende?! Uma coisa incrível! Desconhecidos!... Que nos receberam 
em situações de solidariedade, e o que nos demos de solidariedade também, é uma coisa, eu falava: 'Gente, o povo é muito bom! O povo é muito sofrido, mas é muito bom! Este povo merece que a gente lute! (Mariana)

Podemos perceber, assim, que essas histórias não são apenas de dores e dissabores. Silvia refletiu que se não tivesse sido mãe pela terceira vez, não teria conseguido suportar todo o sofrimento relacionado à maternidade e militância: “(...) eu tinha um sentimento de responsabilidade, chamemos assim, com respeito [ao meu terceiro filho]. Inclusive eu acho que se não tivesse tido [ele], eu não sei o que teria sido, porque ele me manteve conectada minimamente à vida. " (Silvia). O que a experiência dessas mulheres nos permite compreender é que mesmo em um contexto de morte, puderam gerar vida:

...quando tava tendo meu filho eu falei assim, 'que coisa, né? Aqui, nesse lugar de morte surge a vida!" E ninguém fica preso eternamente, meu filho tava no útero... sabe?! Eu acho que a hora que a gente sai do útero, a gente fala 'liberdade!' $E$ você quer andar, você quer ver, você quer a liberdade... Eu acho que a liberdade é o sentimento do ser vivo! A vida exige liberdade. (Sofia)

De forma comum, a memória que se pode depreender dos relatos orais fornecidos apresenta a experiência da maternidade como fenômeno que fortaleceu estas militantes no que se refere ao desejo de viver para lutar hoje, não apenas pelo país, mas em prol de seus filhos que sobreviveram, bem como de tantos outros filhos e mães que não puderam, junto com elas, contar suas histórias. Fato que se anuncia quando estas rompem com o silêncio, registrando através das memórias autobiográficas elementos ainda inéditos para a memória histórica do período.

\section{Considerações finais}

Ao entrar e participar ativamente no mundo da política, as mulheres militantes romperam com a limitação da atuação feminina apenas no espaço privado. Numa atmosfera de abertura desses espaços, modificaram também as concepções de conjugalidade e maternidade assumindo novos modelos de ser mulher e mãe. Contudo, entendemos que, apesar de mudanças, houve também continuidades em certos aspectos no que tange ao seguimento de valores tradicionais, já que, antigos e novos elementos coexistem e mantém relações entre si nas representações do ser mulher. Entender que essas transformações influenciaram as concepções e a possibilidade da ocupação das mulheres em diferentes espaços sociais foi sobremodo relevante, nos fazendo sentir herdeiras dessa história, percebendo que só é possível compreendermos o presente em relação ao passado.

Nos relatos das mulheres militantes, chama-nos à atenção a recorrência de elementos acerca das representações de comunista e de torturador. Tais palavras remetem ao pressuposto da comunicação como algo que impede a classificação das memórias como individuais. As militantes compartilham representações que se organizam na construção da memória, conforme salienta Vázquez (2001) "los discursos que creamos y las palavras que utilizamos generan realidades de las que, en ocasiones, nos resulta muy difícil desprendermos (...) nuestras palavras se incrustam en nuestras prácticas de vida. " (p. 89).

Ainda em relação a tortura em estudo sobre a memória histórica da ditadura militar, Sá, Oliveira, Castro e Möller (2009) revelam que este elemento é constituinte nas representações sobre o período, no que tange as evocações acionadas por pessoas adultas (que durante o 
regime tinham entre 15 e 21 anos), justamente a faixa etária de nossas entrevistadas. No entanto, entre aqueles das amostras de jovens (nascidos após o fim do regime) e idosos (possuíam mais de 24 anos durante o regime), não apresentam o termo tortura como elemento central em suas representações. Neste sentido, os autores pontuam que "O sistema central da representação dos adultos, que viveram o Regime Militar, quando eram jovens, é conciso, crítico e acusador - 'ditadura', 'mortes' e 'tortura'” (p. 254). São elementos que não se apresentam nas representações de jovens e idosos, sendo "ainda mais negativa pelos jovens, embora talvez equivocada, e de forma bem menos rigorosa em idosos" (p. 255). Tais argumentos reforçam ainda mais a contribuição que as memórias autobiográficas destas mulheres podem fornecer para a construção da memória histórica do período, tendo em vista que as experiências narradas, não encontram muitas outras formas de registro e mobilização.

Desta maneira, entendemos que este estudo não encerra e nem esgota o tema aqui abordado, tendo em vista que estas são experiências tão desconhecidas e profundas em seu significado. Mais do que discutir o sentido das realidades vividas, desnudam-se sentimentos, tensões e falas que revelam aspectos da vida pouco compartilhados, mas que permeiam a história do nosso país. Compreender essas experiências neste contexto de transformações torna-se também uma contribuição para o campo de estudos entorno dos aspectos psicossociais da memória, ao possibilitar, por meio dessas versões, a construção de uma memória histórica do período (Sá, 2007, 2009, 2013).

\section{Referências}

Almeida, M. H. T., \& Weis, L. (1997). Carro-Zero e Pau-de-Arara: o cotidiano da oposição de classe média ao regime militar. In F. A. Novais. (Coord.). L. M. Schwarcz. (Org). História da vida privada no Brasil: contrastes da intimidade contemporânea (Vol. 4, pp. 320-408). São Paulo: Companhia das Letras.

Barbosa, P. Z., \& Rocha-Coutinho, M. L. (2007). Maternidade: novas possibilidades, antigas visões. Psicol. Clin., 19(1), 163-185.

Barbosa, P. Z., \& Rocha-Coutinho, M. L. (2009). Ser mulher hoje: a visão das mulheres que não desejam ter filhos. Psicologia e Sociedade, 24(3), 577-587.

Badinter, E. (1985). Um amor conquistado: o mito do amor materno (W. Dutra, Trad.). Rio de Janeiro: Nova Fronteira.

Bardin, L. (2009). Análise de conteúdo. (L. A. Reto \& A. Pinheiro, Trad.). Lisboa: Edições 70.

Bassanezi, C. (2004). Mulheres dos Anos Dourados. In M. D. Priori. (Org). História das Mulheres no Brasil (7a ed., pp. 607-639). São Paulo: Contexto.

Biasoli-Alves, Z. M. M. (2000). Continuidades e Rupturas no papel da mulher brasileira no século XX. Psicologia: Teoria e Pesquisa, 16(3), 233-239.

Boccoline, C. S., Carvalho, M. L., Oliveira, M. I., \& Vasconcellos, A. G. G. (2011). Fatores associados à amamentação nas primeiras horas de vida. Revista Saúde Pública [online], 41(1), 69-78. Recuperado em outubro, 2012, de http://www.scielo.br/scielo.php?pid=S0034-89102011000100008\&script=sci_arttext.

Bonomo, M., Trindade, Z. A., Souza, L., \& Coutinho, S. M. S. (2008). Representações sociais e identidade em grupos de mulheres ciganas e rurais. Psicologia, 22(1). Recuperado em 05 de agosto, 2012, de http://www.scielo.gpeari.mctes.pt/scielo.php?script=sci_arttext\&pid=S0874-

20492008000100007\&lng=pt\&nrm=iso. 
Carneiro, S. (1994). Identidade Feminina. In H. I. B. Saffioti \& M. Muñoz-Vargas. (Orgs.). Mulher brasileira é assim (pp. 187-193). Rio de Janeiro: Rosa dos Tempos.

Carson, A. C. (1995). Entrelaçando consensos: reflexões sobre a dimensão social da identidade de gênero da mulher. Cadernos Pagu, (4), 187-218.

Chauí, M. (1987). A tortura como impossibilidade da política. In E. Branca. (Org.). I Seminário do Grupo Tortura Nunca Mais: depoimentos e debates (pp.28-37). Petrópolis: Vozes.

Coimbra, C. (2004). Gênero, militância, tortura. In M. P. R. Jaeger, F. Pires \& N. S. Azambuja (Orgs). Violência, gênero e políticas públicas (pp. 45-61). Porto Alegre: EDPUCRS.

Colling, A. M. (1997). A resistência da mulher à ditadura militar no Brasil. Rio de Janeiro: Record.

Ferreira, E. F. X. (1996). Mulheres militância e memória: histórias de vida, histórias de sobrevivência. Rio de Janeiro: Fundação Getúlio Vargas.

Gianordoli-Nascimento, I. F., Trindade, Z. A., \& Santos, M. F. S. (2007). Mulheres militantes contra a ditadura: a representação social de "mulher militante" para mulheres que participaram de organizações de esquerda entre 1969-1971. Trabalho apresentado na V Jornada Internacional e III Conferência Brasileira sobre Representações Sociais. Recuperado em 13 de agosto, 2011, de http://www.vjirs.com.br/completos/VJIRS_0336_0360.PDF.

Gianordoli-Nascimento, I. F., Trindade, Z. A., \& Santos, M. F. S. (2012). Mulheres e militância: encontros e confrontos durante a ditadura militar. Belo Horizonte: Editora UFMG.

Gianordoli-Nascimento, I. F., Veloso, F. G. C., Silva, S. A. C., Cruz, J. P. D., \& Oliveira, F. C. (2012). A memória histórica da ditadura militar brasileira: contribuição das narrativas de familiares de presos políticos. Psicologia \& Saber Social, 1(1), 103-119. Recuperado em 09 de janeiro, 2013, de http://www.epublicacoes.uerj.br/index.php/psi-sabersocial/article/view/3249/2258.

Goldenberg, M. (1997). Mulheres e Militantes. Estudos Feministas, 5(2), 349-363.

Halbwachs, M. (1990). A Memória Coletiva. São Paulo: Vértice.

Joffily, M. (2013). No centro da engrenagem: os interrogatórios na Operação Bandeirantes e no DOI de São Paulo (1969-1975). São Paulo: Edusp.

Lozano, F. G. (2007). Mujer y dictadura. In C. S Wolff, M. Fáveri \& T. R. O. Ramos (Orgs.). Leituras em Rede: gênero e preconceito (pp.77-93). Florianópolis: Ed. Mulheres.

Macedo, P. O., Progianti, J. M., Vargens, O. M. C., Santos, V. L. C., \& Silva, C. A. (2005). Percepção da dor pela mulher no pré-parto: a influência do ambiente. Revista de Enfermagem da UERJ, 13, 306-312. Recuperado em 24 de janeiro, 2013, de http://www.facenf.uerj.br/v13n3/v13n3a03.pdf.

Matos, M. I. S. (1995). Do público para o privado: redefinindo espaços e atividades femininas (1890-1930). Cadernos Pagu, (4), 97-115.

Minayo, M. C. S. (Org.). (2010). Pesquisa Social: teoria, método e criatividade (29a ed.). Petrópolis: Vozes.

Perrot, M. (2005). Práticas da memória feminina. In M. Perrot. As mulheres ou os silêncios da história (V. Ribeiro, Trad., pp.33-43). Bauru: Edusc.

Pietrocolla, L. G. (1996). Anos 60/70: do sonho revolucionário ao amargo retorno. Tempo Social, 8(2), 119-145.

Pollak, M. (1989). Memória, esquecimento e silêncio. Estudos Históricos, 2(3), 3-15.

Ridenti, M. S. (1990). As mulheres na política brasileira: os tempos de chumbo. Tempo Social: Revista de Sociologia, 2(2), 113-128.

Rocha-Coutinho, M. L. (1994). Tecendo por trás dos panos: a mulher brasileira nas relações familiares. Rio de Janeiro: Rocco. 
Rocha-Coutinho, M. L. (2009). De volta ao lar: mulheres que se afastaram de uma carreira profissional para melhor se dedicar aos filhos. Retrocesso ou um "novo" modelo de família?. In T. Féres-Carneiro. (Org.). Casal e família: permanências e rupturas (pp. 219-235). São Paulo: Casa do Psicólogo.

Sá, C. P. (2007). Sobre o campo de estudo da memória social: uma perspectiva psicossocial. Psicologia Reflexão e Crítica, 20(2), 290-295.

Sá, C. P. (2009). A memória histórica numa perspectiva psicossocial. Morpheus, 14, 91-100.

Sá, C. P. (2013). A psicologia social da memória: uma sistematização conceitual. In C. P. Sá, P. R. M. Menandro \& L. A. M. Naiff (Orgs.). Psicologia Social e o estudo da memória histórica: o caso dos anos dourados do Brasil. (pp. 13-26). Curitiba: Appris.

Sá, C. P., Oliveira, D. C., Castro, R. V., \& Möller, R. C. (2009). A construção e o estado atual de uma memória histórica: o caso do regime militar no brasil (1964-1985). In A. M. O. Almeida \& D. Jodelet (Orgs.). Representações Sociais: interdisciplinaridade e diversidade de paradigmas (pp. 245-265). Brasília: Thesaurus.

Sarmento, R., \& Setúbal, M. S. V. (2003). Abordagem psicológica em obstetrícia: aspectos emocionais da gravidez, parto e puerpério. Revista de Ciências Médicas, 12(3), 261-268. Recuperado em 18 de maio, 2013, de http://periodicos.puc-campinas.edu.br/seer/index.php/cienciasmedicas/article/view/1260/1235.

Sarti, C. (2004). O feminismo brasileiro desde os anos 1970: revisitando uma trajetória. Estudos Feministas, 12(2), 35-50.

Scavone, L. (2004). Dar a vida e cuidar da vida: feminismo e ciências sociais. São Paulo: Editora UNESP.

Souza, L. (2004). Processos de categorização e identidade: solidariedade, exclusão e violência. In L. Souza \& Z. A. Trindade. (Orgs.). Violência e exclusão: convivendo com paradoxos (pp.57-74). São Paulo: Casa do Psicólogo.

Trindade, Z. A. (1998). Concepções de maternidade e paternidade: o convívio atual com fantasmas do século XVIII. In L. de Souza, M. F. Q. de Freitas \& M. M. P. Rodrigues. (Orgs.). São Paulo: Casa do Psicólogo.

Trindade, Z. A. (1999). Concepções arcaicas de maternidade e paternidade e seus reflexos na prática profissional. Interfaces, 2(1), 33-40.

Vaitsman, J. (1994). Flexíveis e Plurais: identidade, casamento e família em circunstâncias pós-modernas. Rio de janeiro: Rocco.

Vázquez, F. (2001). La memoria como acción social: Relaciones, significados e imaginario. Barcelona: Paidós.

Veloso, F. G. C., Gianordoli-Nascimento, I. F., \& Ferreira, P.R. (2010). A representação social de maternidade entre mulheres que lutaram contra o regime militar no Brasil. In Fazendo o Gênero 9: diásporas, diversidades, deslocamentos, 9 (pp.1-8). Florianópolis: Anais eletrônicos do Fazendo o Gênero 9. Recuperado em 13 de agosto,2011, de

http://www.fazendoogenero.ufsc.br/9/resources/anais/1278277901_ARQUIVO_TrabalhoompletoFazgenero Maternidadeenviado.pdf. 